\title{
Hyperresolution information and hyperresolution ignorance in modelling the hydrology of the land surface
}

Article

Accepted Version

Beven, K., Cloke, H., Pappenberger, F., Lamb, R. and Hunter, N. (2015) Hyperresolution information and hyperresolution ignorance in modelling the hydrology of the land surface. Science China Earth Sciences, 58 (1). pp. 25-35. ISSN 18691897 doi: https://doi.org/10.1007/s11430-014-5003-4 Available at https://centaur.reading.ac.uk/38446/

It is advisable to refer to the publisher's version if you intend to cite from the work. See Guidance on citing.

Published version at: http://earth.scichina.com:8080/sciDe/EN/abstract/abstract516005.shtm/\#

To link to this article DOI: http://dx.doi.org/10.1007/s11430-014-5003-4

Publisher: Science China

All outputs in CentAUR are protected by Intellectual Property Rights law, including copyright law. Copyright and IPR is retained by the creators or other copyright holders. Terms and conditions for use of this material are defined in the End User Agreement.

www.reading.ac.uk/centaur 
Central Archive at the University of Reading

Reading's research outputs online 


\title{
Hyperresolution information and hyperresolution ignorance in modelling the hydrology of the land surface
}

\author{
Keith Beven ${ }^{1}$, Hannah Cloke², Florian Pappenberger ${ }^{3}$, Rob Lamb ${ }^{4}$ and Neil Hunter ${ }^{5}$ \\ ${ }^{1}$ Lancaster Environment Centre, Lancaster University, Lancaster LA1 4YQ, UK and Department of Earth \\ Sciences, Uppsala University, Uppsala, Sweden. \\ ${ }^{2}$ Department of Geography and Environmental Science, University of Reading, Reading, UK \\ ${ }^{3}$ Department of Meteorology, University of Reading, Reading, UK \\ ${ }^{4}$ European Centre for Medium-range Weather Forecasts, Reading, UK. \\ ${ }^{5}$ JBA Trust, South Barn, Broughton Hall, Skipton, BD23 3AE UK \\ ${ }^{6}$ JBA Consulting, South Barn, Broughton Hall, Skipton, BD23 3AE UK
}

\begin{abstract}
There is a strong drive towards hyperresolution earth system models in order to resolve finer scales of motion in the atmosphere. The problem of obtaining more realistic representation of terrestrial fluxes of heat and water, however, is not just a problem of moving to hyperresolution grid scales. It is much more a question of a lack of knowledge about parameterisation of processes at whatever grid scale is being used for a wider modelling problem. Hyperresolution grid scales cannot alone solve the problem of this hyperresolution ignorance. This paper discusses these issues in more detail with specific reference to land surface parameterisations and flood inundation models. The importance of making local hyperresolution model predictions available for evaluation by local stakeholders is stressed. It is expected that this will be a major driving force for improving model performance in the future.
\end{abstract}

\section{Introduction}

It is a general expectation in earth system science modelling that we will continue to move to higher and higher resolution coupled models, with so called hyperresolution models (on the order of $1 \mathrm{~km}$ or less) becoming computationally feasible for operational forecasts within the foreseeable future (e.g. Wood et al., 2011). Many of the forecasting centres that produce global Numerical Weather Predictions (NWP) are already running tests with models at such scales or have plans to move to scales of the order of $1-10 \mathrm{~km}$ in the near future. Many Limited Area Models are already run at hyperresolution. It is also likely that global climate models will follow in due course again with some regional climate models already running at such scales. The principle driver behind these developments is to resolve finer scales of motion in the atmosphere and oceans, with an expectation that the accuracy and precision of forecasts and projections will be improved. Past experience suggests that this will be the case. There have been improvements in both forecast performance and lead times as more powerful computers have become available and grid scales have reduced and as the observed data available for assimilation have increased (e.g. Richardson et al., 2013).

In NWP and climate models both atmosphere and ocean are represented in the form of continuum nonlinear partial differential equations for the conservation of mass and momentum, which can only be solved approximately. In particular, the way in which the differentials can be approximated depends on the grid scale and how well the scales 
of motion can be represented depends on the Nyquist frequency (at approximately twice the grid scale). Thus in the representation of the fluid dynamics, grid scale is a major factor in modelling accuracy. Processes operating at less than the grid scale, including the dissipation of energy due to finer scale turbulence, must then be parameterised. Because of a lack of knowledge of the details of sub-grid processes, including non-homogeneous turbulence close to boundaries and complex interacting boundary layers over heterogeneous surfaces, such sub-grid scale parameterisations are often empirical or conceptual in nature.

There are, however, also parts of the earth system that are not so easily represented in the form of continuum partial differential equations above the very fine scale. In particular, the transport of heat and water in the terrestrial subsurface is better represented by imposing mass and energy balances with closures at the scale of discrete elements of the landscape rather than making fluxes dependent on gradient terms at anything above cm scales (e.g. Beven, 2006). In fact, the concept of a simple continuum gradient will generally be meaningless in the subsurface, where heterogeneity of characteristics, preferential flows, and the local nonlinearity of flow processes will be paramount. At a grid scale of $1 \mathrm{~km}$ or even $100 \mathrm{~m}$, there is heterogeneity of topography, soil, geology and vegetation that will greatly influence the boundary fluxes across grid squares and exchanges between the land surface and the atmosphere. Even at $10 \mathrm{~cm}$, there can be preferential heterogeneity of water and heat flows that do not reflect continuous gradients in grid-scale variables other than the effect of gravity (with the possible exception of saturated water flows in larger groundwater bodies but even then the effects of heterogeneities may be obscured by the limitations of observational techniques in the subsurface).

It is therefore necessary to provide sub-grid parameterisations of such processes. This is a problem that has been discussed for a long time in hydrological modelling (e.g. Beven, 1989), but for which no definitive answer has been developed. Different models provide different forms of sub-grid parameterisations, including both conceptual storage models and models that continue to solve the continuum equations for the subsurface without recognition of the limitations of such an approach. Many current land surface parameterisations used in earth system models are peculiar mixtures of these two approaches, including the Community Land Model (Lawrence et al, 2011) and Joint UK Land Environment Simulator (JULES) (e.g. Blyth et al., 2010). This results from the fact that our knowledge of such grid-scale land surface characteristics and grid-scale integrated fluxes is subject to significant knowledge or epistemic uncertainties (Beven, 2012; Beven and Cloke, 2012). Comparisons with fluxes at a point (as in Blyth et al., 2010) gives only a limited constraint on any parameterisation, especially when the subsurface boundary conditions are unknown. Since there is then no correct answer, there is more than enough scope for multiple processes representations and parameterisations.

Thus, the problem of obtaining more realistic representation of terrestrial fluxes of heat and water is not just a problem of moving to hyperresolution grid scales. It is much more a question of a lack of knowledge about parameterisation of processes at whatever grid scale is being used for a wider modelling problem. Hyperresolution grid scales cannot alone solve the problem of this hyperresolution ignorance. This paper 
discusses these issues in more detail, with some suggestions for future work necessary to make progress in this area.

\section{Hyperresolution information}

There is no doubt that there is more information about the earth, atmosphere and oceans available than ever before. In part this is due to the wider deployment of observations systems such as the International Soil Moisture Network (Dorigo et al., 2011); FLUXNET (Wilson et al., 2002; http://daac.ornl.gov/FLUXNET/fluxnet.shtml) and Cosmic Ray Soil Moisture Observing System (COSMOS; Zreda et al., 2012; Chrisman and Zreda, 2013; http://www.ceh.ac.uk/cosmos/), although there is evidence that globally hydrological observing systems are being reduced or may contain major inconsistencies (Hannah et al., 2011; Kauffeldt et al., 2013). More important, however, has been the deployment of more satellite remote sensing systems that have led to unprecedented volumes and detail of data that can be used in data assimilation, model evaluation and reanalysis (e.g. Dee et al., 2011). Much of this remotely sensed data is available directly at hyperresolution scales, and in some cases down to sub-meter scales. Many data sets such as the NASA 2000 Shuttle Radar Topography Mission (SRTM, at 3 arc-second or about $90 \mathrm{~m}$ resolution) and the ASTER (Advanced Spaceborne Thermal Emission and Reflection Radiometer) stereoimaging topography product (at $30 \mathrm{~m}$ resolution) are freely available, leading to dramatic improvements in the way in which it is possible to represent the shape of the land surface. Locally this can be augmented by airborne LIDAR (Laser Distance and Ranging) systems with resolutions down to sub-metre scale, though this may require processing to distinguish the land surface topography from vegetation and buildings etc. (e.g. Antonarakis et al., 2008; Casas et al., 2010)

Clearly the availability of high resolution topographic data is directly relevant to fluxes both at the surface, in the atmosphere and in the subsurface. That was the one type of hyperresolution data that was easily demonstrated to have an impact by Wood et al. (2011). Other types of information available at hyperresolution scales, such as surface temperatures, are also directly relevant to the fluxes of water and heat but are generally limited to providing information at, or very close to, the land surface. Very often, however, such remote sensing data demonstrate very nicely the type of sub-grid scale variability and changes over time that are often neglected by the sub-grid parameterisations used in larger scale models (see for example Franks and Beven, 1997).

However, the advantages of moving to higher resolution in adding information are also evident in model outputs, particularly in atmosphere and ocean models. For example, over the last decades NWP models have continuously increased in resolution. leading to better images of particular synoptic features. For example, ECMWF increased its model resolution from $\sim 210 \mathrm{~km}$ in 1981 to $16 \mathrm{~km}$ in 2013 , which in turn leads to more realistic looking model outputs. This gives greater definition in the forecast outputs, especially in cases of extreme events (see the hurricane of Figure 1 and studies on the forecasting of local extreme rainfall events as reported in Golding, 2009). There is also a general expectation, based on past experience, that greater definition will be followed by greater accuracy and confidence in the forecasts and predictions of such models over 
longer lead times even if we also expect that in the longer term there will continue to be divergence in ensemble forecasts.

At local scales, of course, it is possible to go further in using finer resolution models to resolve convection (Weusthoff et al., 2010; Baldauf et al., 2011), and there is an interesting issue that arises as atmospheric models move towards convection resolving scales as to how their various sub-grid parameterisations, for example of rainfall formation, should be modified.
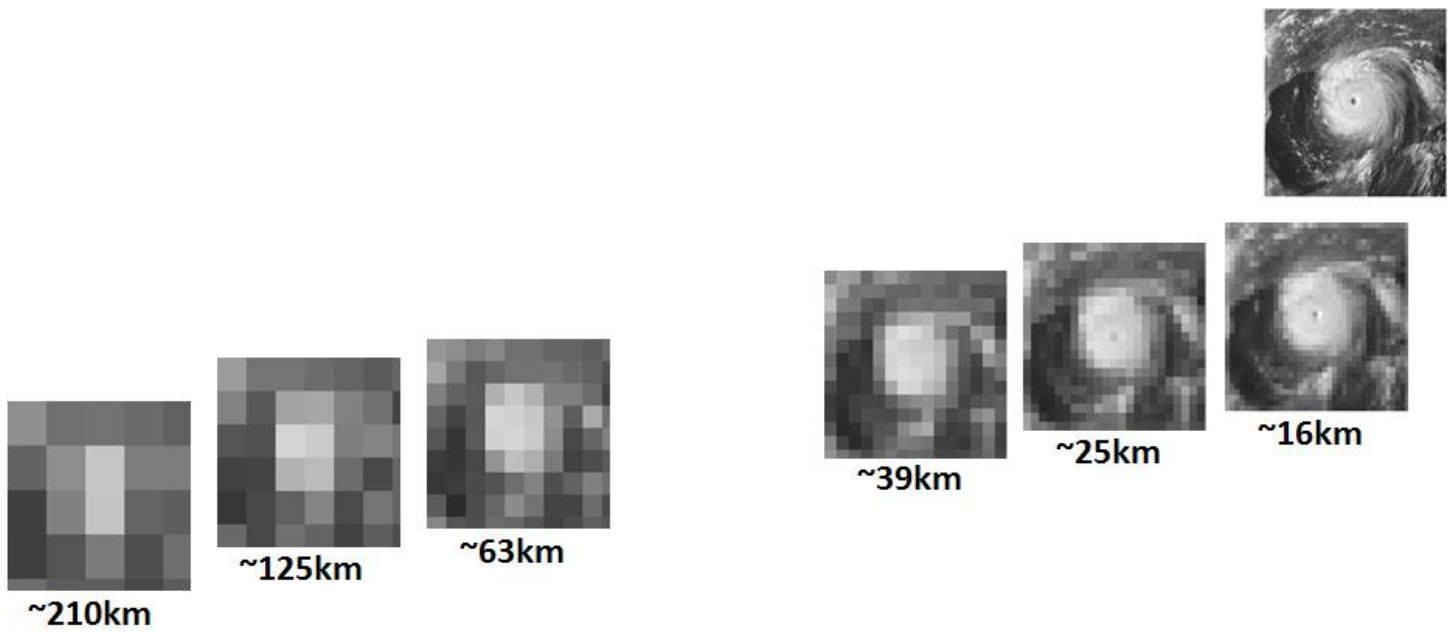

Figure 1. Resolving a large scale hurricane system at different levels of resolution. The top image is the higher resolution data from the visible light wavelengths of the NASA TERRA satellite MODIS sensor (1 $\mathrm{km}$ pixels). The other images -present the same data but at the various resolutions of past and present ECMWF Numerical Weather Prediction models (source WWw.ecmwf. int).

Demonstrating realism in the representation of terrestrial subsurface processes is much more difficult because, as noted already, of the lack of knowledge of subsurface characteristics and boundary conditions. In this domain as well, however, increased computer power has led to the use of finer resolution models but mostly in hypothetical virtual reality simulations to explore the impacts of subsurface heterogeneities on flow and transport processes. This type of study also has a long history, from the early random field experiments of Freeze (1975, 1980), Smith and Schwarz (1980) and Smith and Hebbert (1979) to the recent multimillion element simulations of, for example, Zinn and Harvey (2003), Feyen and Caers, (2006), Michael et al. (2010), Guilleminot et al. (2012), and Meerschaert et al., (2013).

An interesting example is the study of Bashford et al. (2002) who produced virtual reality simulations of the $538 \mathrm{~km}^{2}$ Little Washita catchment in Oklahoma. The outputs of the model are estimates of the surface and subsurface water flows and stream discharges and fluxes of latent and sensible heat to the atmosphere. Variation in the actual catchment topography on water flow and availability for evaporation, and the effects of random heterogeneities of soil characteristics and rainfall inputs to the hydrological model were reproduced. This meant that integral fluxes at any grid scale could also be calculated. In particular they looked to see what complexity of sub-grid 
parameterisation might be supported if a direct measurement of actual latent heat fluxes was available at the $1 \mathrm{~km}$ grid scale (with some uncertainty in the signal). It turned out that only a rather simple parameterisation of the decline of actual evapotranspiration with topsoil moisture content could be identified robustly from the (virtual) observations at this $1 \mathrm{~km}$ scale. The local heterogeneity certainly affects the observation at the sensor but presents a simpler signal integrated to this scale.

Other cases might be more problematic. Some early work on stochastic fields in hillslope hydrology suggested that an integrated measurement of discharge at the $500 \mathrm{~m}$ scale from a heterogeneous soil might be represented by an equivalent homogeneous hydraulic conductivity for cases where the response was dominated by subsurface stormflows. When there were coupled surface and subsurface responses, however, no equivalent effective hydraulic conductivity could be found that would consistently reproduce the discharges (Binley et al., 1989a,b). These are virtual experiments, of course, but might be indicative of the problems that might be met in representing complex nonlinear interacting processes for real catchments of unknown heterogeneity. The simple use of small scale theory with "effective" homogenous values of parameters might not be adequate.

And yet, this is the approach that has been taken in nearly all parameterisations of land surface processes in atmospheric models. These have also continued to be mostly "flat earth" parameterisations, with little or no account taken of the role of topography and geology in changing the patterns of available water and runoff generation in the landscape (see, for example, Pacific et al., 2011; Emanuel et al., 2013). We might expect to include more detailed information (and perhaps do better) as we move to finer resolutions (e.g. Kollett et al, 2010), but resolution alone does not solve the problems of knowing patterns of relevant parameters in the landscape. In general, finer scale observations will not provide estimates of such parameters, they will have to be calibrated in some way to be consistent with the observations (or data assimilation used in forecasting to compensate for the deficiencies in the sub-grid parameterisations). Soil moisture is a hydrological variable that can be measured by airborne or space remote sensing. The Soil Moisture Active and Passive (SMAP) microwave mission will have an active L-band radar giving soil moisture information at 10km resolution every 2-3 days when it is launched in 2014-15 (Entekhabi et al., 2010). But the soil moisture sensed by active or passive microwave sensing is limited to the top few $\mathrm{cm}$ of soil, with uncertainties of a few percent because of surface roughness and other factors. In addition, the dielectric constant of the soil, on which the microwave emissivity depends, becomes rather insensitive when the soil is either very wet or very dry, increasing the uncertainty. Making use of such data might also depend on other, non-hydrological model components (e.g. Tian et al., 2009). The resulting inverse problem to find effective parameters consistent with such data will clearly be difficult and will not be made any easier by moving to hyperresolution models when more and more local parameters will need to be provided to run such models.

These examples suggest that there is a certain tension between resolution and information or knowledge that depends on the dynamics of the system. In moving from low resolution to higher or hyperresolution models there is initially a gain in information in resolving major features of the dynamics (synoptic scale features in the atmosphere and oceans, the topography of catchments on the land surface). Finer 
resolution helps resolve more dynamic scales, and helps in the differentiation of boundary conditions and system characteristics that might affect the dynamics. But at a certain level this gain will plateau out when a simple increase of resolution will bring no improvement because there is a lack of knowledge about how best to represent the effects of heterogeneity in the boundary conditions and system characteristics. It is at this point that ignorance starts to play a more important role. Beyond that point it might be that the epistemic uncertainties associated with that ignorance might lead to feedback to large scales of motion and constrain the gain that might be expected with increased resolution.

It is also possible to envisage cases where the simple increase in resolution of input data to a hyperresolution model might lead to the introduction of disinformation into the modelling process. This could arise where there is epistemic error about the type of interpretative model that is appropriate in using such data. Is it adequate to use a based model in the assimilation of remote sensed surface soil moisture (for example, Mohanty, 2013), where such models have long been criticised as a representation of soil water flow processes (e.g. Beven and Germann, 1982, 2013). Similarly, surface topography is now often available to very high resolution, but will not necessarily provide an adequate representation of downslope connectivity and flow pathways (e.g. Freer et al., 2002). It may only be broadly right in reflecting the dominant effect of gravity on downslope flow processes (e.g. Smith et al., 2013).

\section{Hyperresolution ignorance}

In the terrestrial subsurface we are ignorant of much of what goes on in the detail of flow and transport processes. Advances in geophysics have made some progress in revealing subsurface structures and, for example, patterns of wetting and drying (e.g. Binley and Beven, 2003; Musgrave and Binley, 2011; Perri et al., 2012). Some techniques, such as 3D X-ray computed tomography scans can show patterns of water flows in great detail, but only on small samples, destructively sampled and brought back to the laboratory. Other techniques, such as electrical resistance tomography or radar can be used in the field, but with a trade-off between the size of the domain sampled and the resolution of the imaging. In addition, the inverse problem in obtaining such images is generally not well posed and some form of regularisation is often imposed to obtain a solution (Lelièvre and Farquharson, 2013). Even then, field geophysics is not sufficiently detailed to determine all the preferential flow pathways through the soils, nor does it give sufficient coverage to provide information across a network of hyperresolution elements for a catchment or other flow domain.

Although in some cases hyperresolution scale information from remote sensing or Geographical Information System (GIS) map layers is available, in most cases considerable ignorance remains at hyperresolution scales. As already noted above, we may have digital numbers representing microwave emissivity but there may significant uncertainty in how to interpret that in terms of surface soil moisture, especially where raw remote sensing data have been processed through models with uncertain parameters before those digital number images are released for use by others. We may have soil, geology or land use maps but there may be a lot of uncertainty in how to interpret those maps in terms of the effective parameter values required by models. In 
addition, we are actually a long way behind in many global fields. For example, GRACE (Gravity Recovery and Climate Experiment, http://www.csr.utexas.edu/grace/) gravity determination of groundwater is a very popular global information source, and in principle is very exciting - but the resolution is far from what might be considered as hyperresolution and will be for the foreseeable future (Wang et al., 2013).

These are examples of how there is not a problem in principle of moving to hyperresolution scales of discretisation but how in doing so we start to run up against the hyperresolution ignorance or epistemic uncertainties of what is actually occurring in the subsurface. Domain resolution is then less of an issue than knowing the domain characteristics and boundary conditions, about which there is also be a degree of epistemic (and perhaps aleatory) uncertainty that will constrain how well we can simulate any observations. This is seen, for example, in the case of the development of a model for the R5 catchment at Chickasha (see Loague, 1990; Loague et al., 2000; Heppner et al., 2007) and in the attempt to model the Coos Bay headwater catchment (before it became a debris flow) (e.g. Ebel et al. 2008). In such cases, there are also issues about whether the data are actually good enough to be able to test models as hypotheses of how the catchment functions (Beven, 2010, 2102; Beven et al., 2011, 2012a; McMillan et al., 2010, 2012; Beven and Westerberg, 2011; Beven and Smith, 2014).

Another issue relative to moving to finer scales is that we should not expect either process representations or effective parameter values to be independent of scale. This is the case of the representation of convection in the atmosphere; it is also the case for the representation of surface and subsurface flows on hillslopes in hydrology. On hillslopes, the representation of hysteresis in the storage/boundary flux relationship will depend on the scale of the landscape unit being considered because of the way that the flux response is dependent on the celerity and hence the length scale (Beven, 2006; McDonnell and Beven, 2014).

There is thus a problem of the effective resolution of a model and the perceived resolution at which results are calculated and visualised to users. With hyperresolution topographic data available, an impression can be given that detailed process representations have been specified at that scale. Visualisations on Google Earth can allow users to zoom into this finer detail, as if the virtual reality that has been created was the truth. This is quite natural, especially if the user has some special interest in a particular locality, but might be quite misleading. Adding resolution in the presentation of model simulation results, does not necessarily add information for the user, where the model may be subject to important epistemic uncertainties. It can, however create a dangerous illusion of information where much ignorance may remain at hyperresolution scales.

\section{The effect of ignorance on the information content of model simulations.}

There are many past examples of how ignorance might compromise the information content of model simulations. From a hydrological point of view one of the most important is the hydrological coupling of the land surface - atmosphere interaction, as reflected in the simulation of latent heat fluxes and runoff generation and routing. This 
has long been a mismatch between the process representations used in catchment scale models and the land surface parameterisations used as the boundary conditions for atmospheric models. The latter have ignored much of what is known about how runoff generation processes and the redistribution of water across the landscape work. They have been hydrologically ignorant in that sense. They have also, for good computational reasons, ignored much of what is known about the uncertainty in hydrological parameterisations (e.g. Franks and Beven, 1997). The result is, however, seen in the mismatch between simulated and observed catchment discharges by individual land surface parameterisations (e.g. Gudmundsson et al., 2012).

It follows that if the simulated discharges are in error then the latent and sensible heat fluxes might also be in error, with consequent feedbacks to the atmospheric circulation and downwind precipitation. Although large scale simulations of the land surface make routine comparison of simulated and observed point scale observations of vapour, heat and $\mathrm{CO}_{2}$ to the atmosphere (e.g. Drusch et al., 2007; Albergel et al., 2010; Balsamo et al., 2011; Boussetta et al., 2013), it is not always the case that they can reproduce local point fluxes adequately, even allowing for uncertainty in the observational data (e.g. Mitchell et al., 2009, 2011). There is considerable ignorance about how to relate such point scale measurements to grid scale integral values that the land surface models are intended to predict. Observed and predicted variables might have similar names but might be incommensurate quantities. Yet, such errors will have feedback to changes in the vegetation characteristics with clear implications for long term predictions of change. Comparisons of different land surface models at global scales also reveals significant differences in predictions without any real understanding of what leads to such uncertainties (Haddeland et al., 2011).

This might actually get worse with the implementation of hyperresolution atmospheric models. Such models will resolve higher scales of motion but in their representation of precipitation will become even more dependent on local boundary layer effects and the spatial heterogeneity of hydrological processes. The hydrological and land surface components can also evolve to a finer resolution but significant epistemic uncertainties about the land surface parameters and their effect on local boundary layers and fluxes will remain. Some of that ignorance will necessarily feed back to the atmospheric simulation.

We should perhaps therefore be a little more thoughtful about how to incorporate land surface information into coupled models, and how the parameters of such representations might vary with length scale. We should no longer consider that it is sufficient to take small-scale process representations and simply multiply up by a grid area. In the past, grid scales have just been so much larger than the scales of hillslopes and hydrological responses that this issue has simply been ignored. It will become more important but how best to represent the net effect of such processes at different grid scales is still a basic research need.

\section{The effect of information in constraining the effects of ignorance.}

One way of approaching this problem is to do much more than in the past about rejecting models that are clearly wrong (Beven, 2012; Beven et al., 2012b). This is one 
really good reason for pursuing the development of hyperresolution models since once visualisations of model outputs are available to local users interested in particular places, then those users can examine the model outputs much more critically than has been possible in the past when only summary grid scale variables were output for evaluation. In this way, local users can evaluate local predictions and identify obvious errors. This process will increasingly drive the way that modelling is done in hydrology and other applications. For hydrology, it is already happening in, for example, the Danish National Water Resources Model (Henriksen et al., 2008) which has been revised a number of times, partly driven by local feedback. It is important in such evaluations to ensure that like variables are compared with like. As noted earlier, observed and predicted variables can be incommensurate. This is one justification for the use of downscaling and bias correction techniques when presenting the results of both forecasting and global change models (e.g. Ines and Hansson, 2006; Cloke et al., 2010, 2012; Wilby, 2010; Piani et al., 2011). There is, of course, a danger that bias corrections are simply used to make poor model predictions more acceptable, since there is no reason why bias corrections should be stationary under all past and future conditions.

There will be other examples. Under the European Union Floods Directive, every country in Europe will be tasked with producing maps of areas at risk of significant flooding from all sources. High-resolution models for assessing flood risk have been around for some time (e.g. Lane, 1998) but in the last decade have started to be used with very high resolution topographic data leading to a significant improvement in accuracy. The new maps were released to the public in the UK in December $2013^{1}$. The maps will suggest that some properties, distant from rivers, will be declared as in areas at risk of flooding. Some such properties might have flooded as the result of pluvial flooding in the recent past (such as in Hull in 2007, or Newcastle, in 2012) but others will not have seen any recent flooding.

The maps are therefore likely to be contested and formally challenged, particularly where they preclude building development ${ }^{2}$. They were produced by an agreed and documented procedure (Environment Agency, 2013). The modelling and mapping was at hyperresolution level of detail, defined as follows: The modelling was based on a composite remotely sensed Digital Terrain Model (DTM) that provides a continuous description of "bare earth" topography across England and Wales at a horizontal hyperresolution grid cell resolution of $2 \mathrm{~m}$ (with vertical accuracies quoted as $\pm 0.15 \mathrm{~m}$ or $\pm 1 \mathrm{~m}$, depending on the source of data). These data and precision estimates reflect a 'snapshot' of the landscape at the time of data capture and hence there may be epistemic errors introduced where the landscape has subsequently changed due to processes such as urban or infrastructure development, natural changes, landfill or coastal realignment. Furthermore, the processing used to derive the terrain model from raw remotely sensed data sensor may not always fully resolve the bare earth surface given "clutter" such as trees. Buildings and roads were specially treated within the DTM to allow for partial obstruction to flood flows (buildings) and preferential flow (roads). Previous analysis (e.g. Hunter et al, 2010) has shown that incorporation of buildings can be important in developing accurate mapping (Figure 2).

\footnotetext{
${ }^{1}$ See (http://watermaps.environment-agency.gov.uk/wiyby/wiyby.aspx?topic=ufmfsw).

${ }^{2}$ See discussion following http://www.theguardian.com/environment/2013/dec/12/three-millionproperties-at-risk-flash-flooding
} 

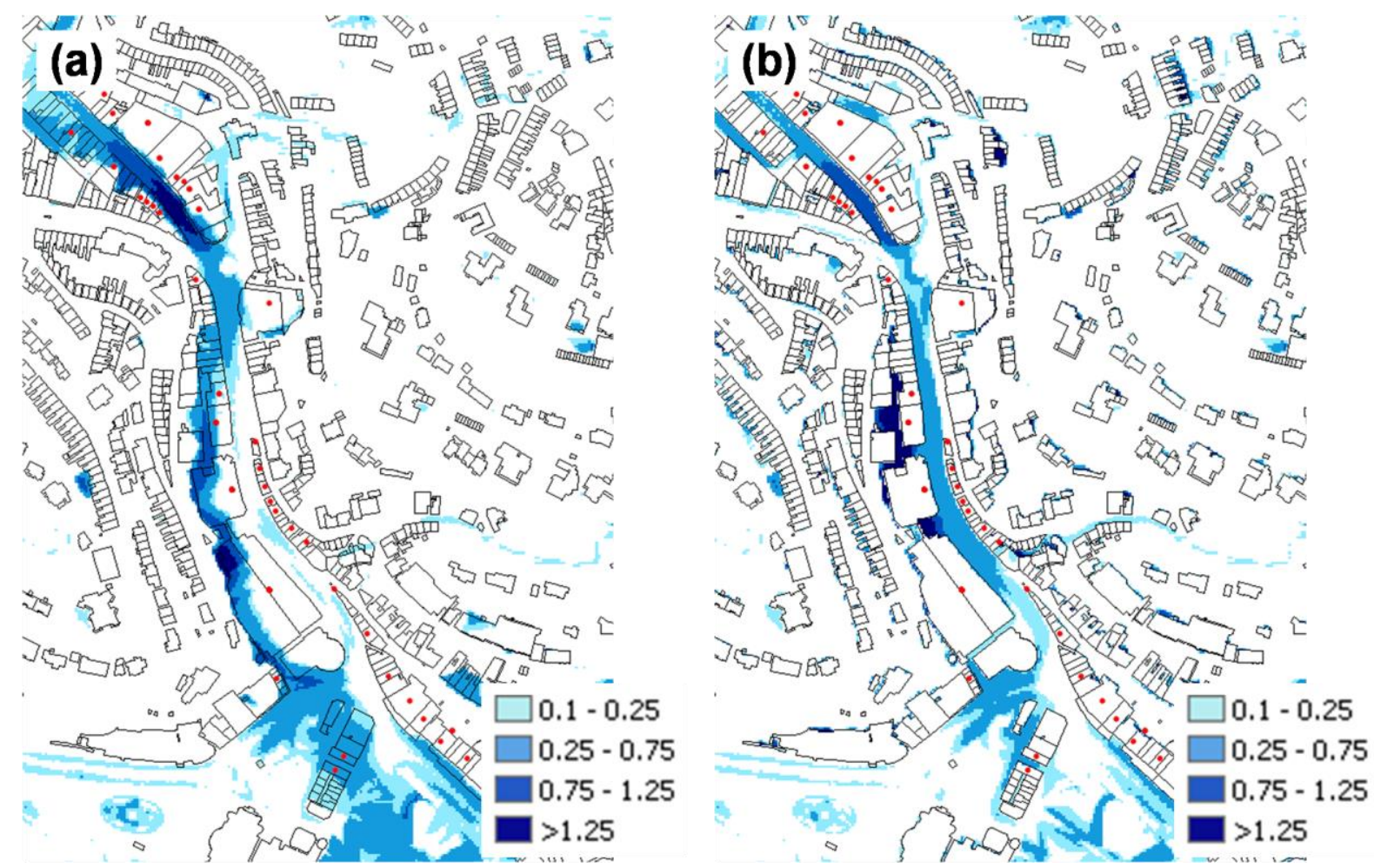

Figure 2. Comparison of maximum flood depths based on $2 \mathrm{~m}$ DTMs without (a) and with (b) buildings for a subset of the Torquay pilot area (reproduced from Hunter et al., 2010 using Ordnance Survey Data, Crown Copyright License 100026380.2010 , all rights reserved).

To achieve the requirement of national scale mapping England and Wales were subdivided into approximately 7,100 overlapping $6 \mathrm{~km}$ x $6 \mathrm{~km}$ "tiles". In each tile, rainfall depth was estimated for a specified exceedance probability using techniques outlined in the Flood Estimation Handbook (Faulkner, 1999). These rainfall values were routed over the $2 \mathrm{~m} \times 2 \mathrm{~m}$ DTM using a hydraulic model that solves the Shallow Water Equations with a conservative, shock capturing numerical scheme, implemented on many fast Graphical Processing Unit (GPU) parallel processors (Lamb et al., 2009; Crossley et al., 2010). Each tile therefore involved modelling 9 million cells, making a total of 63.9 billion cells in the full England and Wales model. The exercise did not consider the additional problem of routing runoff between tiles along larger river channels since fluvial flooding is currently treated separately in defining flood risk maps.

The hyperresolution detail in the surface water modelling and mapping, does not preclude the fact that there are epistemic uncertainties about local rainfalls and their extrapolation to more extreme exceedance probabilities AND the way in which those rainfalls might induce surface runoff in interaction with any infiltrating surfaces and drainage systems. The modelling included rainfall adjustments to reflect, in an aggregate sense, infiltration and some aspects of surface water drainage systems (Figure 3). These adjustments, whilst chosen based on evidence from pilot studies, cannot of course fully represent the dynamics of drainage in a specific flood event at a specific location. Nor could the maps integrate probabilistically over all such possible 
dynamics of drainage system performance. In such circumstances, allowing for different sources of uncertainty in a realistic way can be of advantage to the modeller.

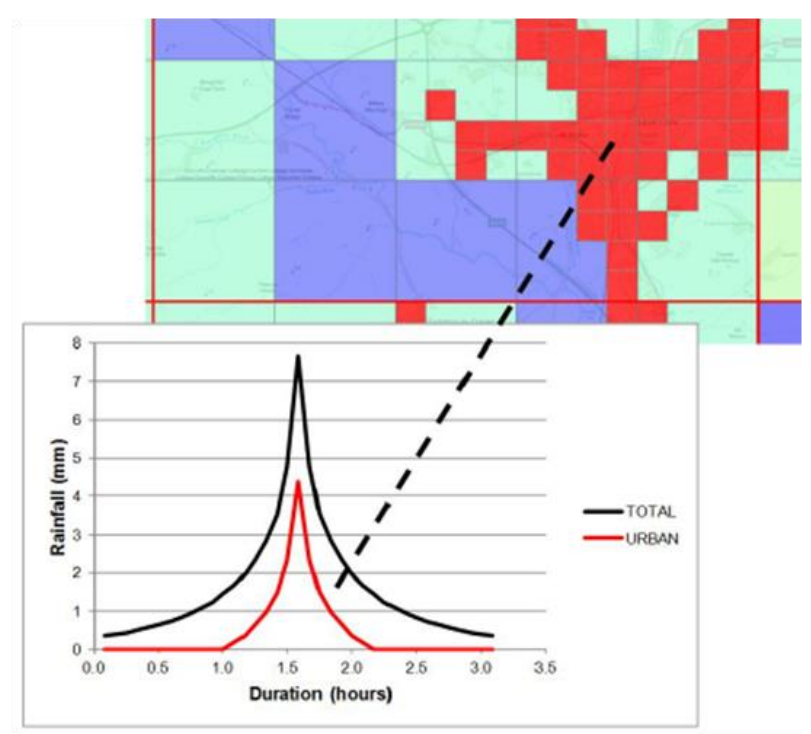

Figure 3. Example of urban area rainfall adjustment applied in models used to derive the 2013 England and Wales surface water flood maps.

For the England and Wales surface water flood mapping, sources of uncertainty were recognised through a process of verification and confidence rating, involving significant engagement and interaction with professional end users of the maps (particularly in local government). Considerable effort was made to place the maps in an appropriate context and provide explanation and guidance on interpretation, in particular through making use of explanatory web pages ${ }^{3}$ and interactive mapping tools ${ }^{4}$. A star rating was used to capture how users' confidence in the mapping varies between locations on a $50 \mathrm{~m} \times 50 \mathrm{~m}$ resolution grid, taking account of quality of input data, topography (steep/flat) and the land cover type (urban/rural). Results were investigated in detail at three test locations where observations exist of localised flooding incidents (utilising 6335 observations in records that capture flood events of 2002 and 2007, amongst others). In addition, users have the opportunity to review and change the confidence star rating, and were encouraged to feedback observations on the maps before deployment (Figure 4).

\footnotetext{
${ }^{3} \mathrm{http} / / /$ www.environment-agency.gov.uk/homeandleisure/31662.aspx

${ }^{4} \mathrm{http}: / /$ watermaps.environment-

agency.gov.uk/wiyby/wiyby.aspx?topic=ufmfsw $\# \mathrm{x}=357683 \& \mathrm{y}=355134 \&$ scale $=2$
} 


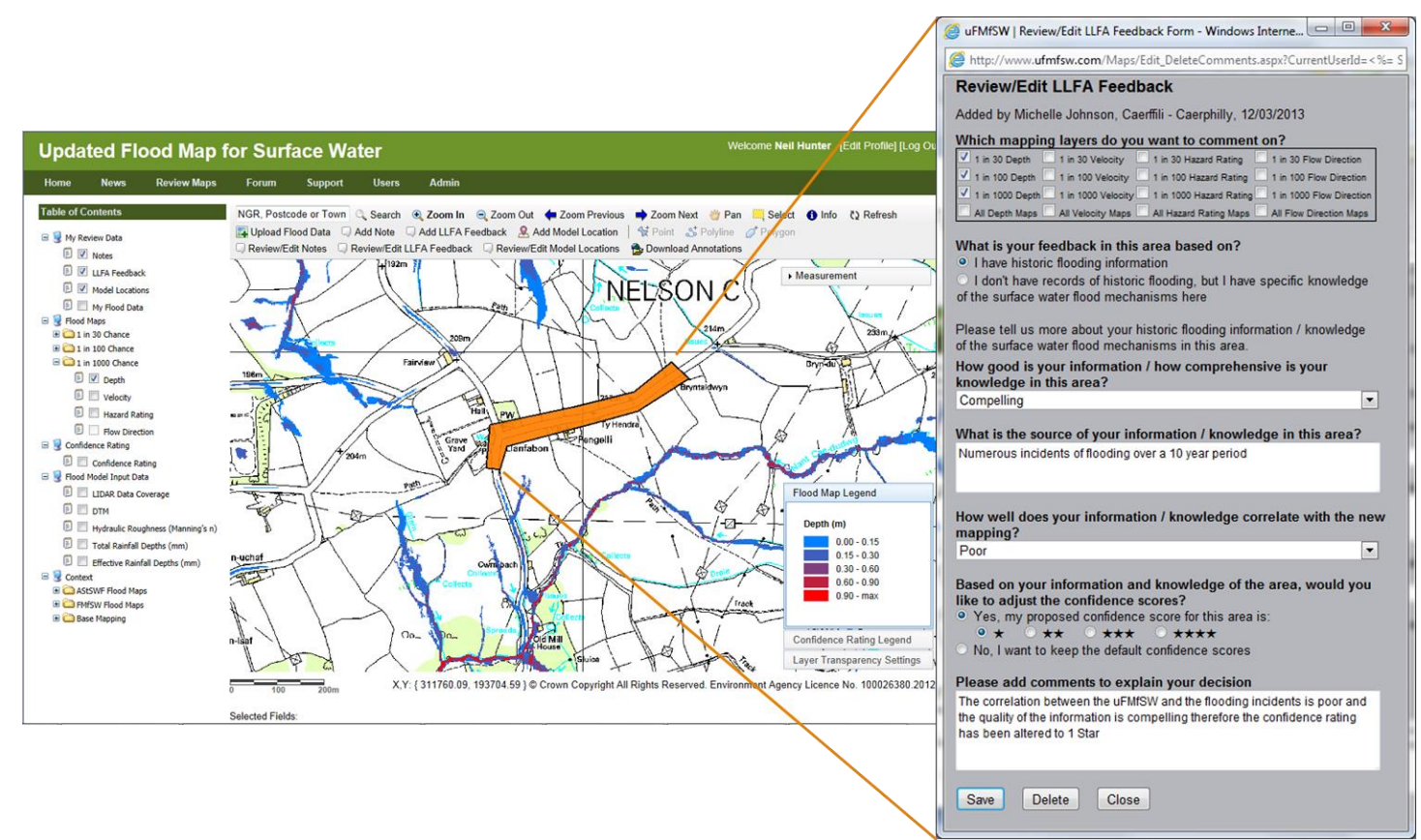

Figure 4. Quality assurance of surface water flooding maps

In such circumstances, allowing for uncertainty in a realistic way is of advantage to the modeller. Uncertain maps are much less likely to be criticised as wrong if they are associated with a realistic assessment of the relevant uncertainties. In some cases it is already possible to make many hyperresolution model runs (at least of limited domains), condition those runs on any available observational data, and present the results as "probabilistic" maps. An example is shown in Figure 5, based on work by Beven et al. (2013, 2014) (see also Leedal et al., 2010; Neal et al., 2013 for other applications). Care should be taken in conveying the meaning of such maps since, as noted earlier, epistemic uncertainty undermines the interpretation of probability as an indicator of potential future outcomes even after conditioning on historical flood inundation observations (e.g. Pappenberger et al., 2007). Communication of the meaning of such maps to professional users should attempt to convey the assumptions that have gone in to the preparation of such maps and, even more importantly, what might have been left out of the uncertainty analysis. Beven et al., (2014) and Beven and Alcock (2012) describe a framework for the application of probabilistic fluvial flood risk mapping. This framework requires explicit definition of the assumptions that underlie any application, which then provides an audit trail for later evaluation and review. Similar issues arise in the context of flood forecasting (e.g. Cloke and Pappenberger, 2009; Alfieri et al., 2013a; Wetterall et al., 2013; Pappenberger et al., 2013; Smith et al., 2014). 


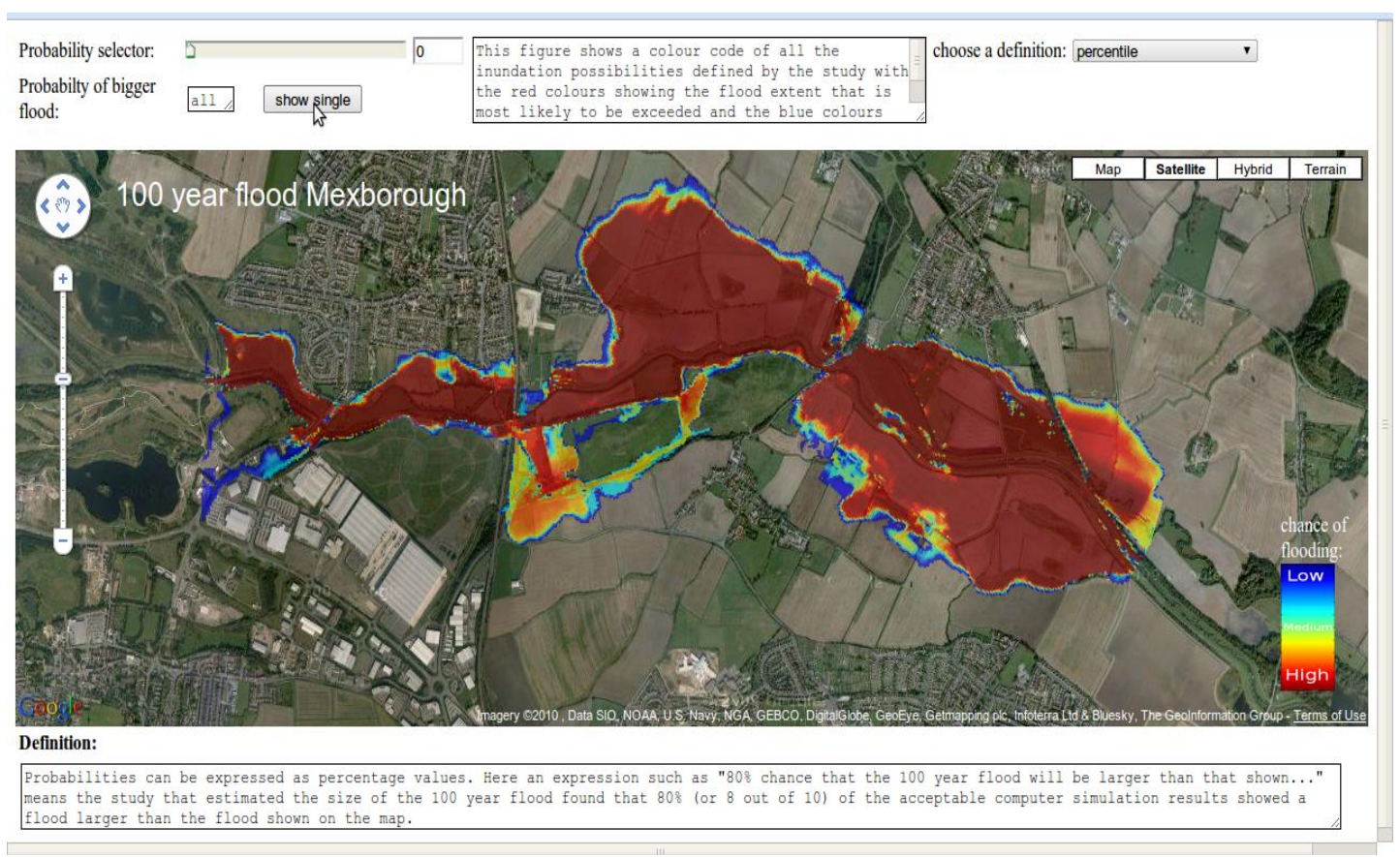

Figure 5. Visualised likelihoods of inundation for the 1\% Annual Exceedance Proability event for Mexborough, Yorkshire, superimposed on Google Maps (from Beven et al., 2014).

An interesting example of the interaction between hyperresolution modellers and the local public in the context of flood mapping has been provided by the Ryedale Flood Project (Odoni and Lane, 2010; Lane et al., 2011; Whatmore et al., 2011). This arose due to a local flood action group trying to find ways of mitigating flooding in the town of Pickering in Yorkshire, when hard defences were deemed not to be justifiable. Maps of runoff sources and zones of inundation were produced as a tool for communication and resulted in significant discussion and revision. This resulted in new suggestions for flood storage areas that could be implemented at minimal cost. This is one way in which hyperresolution modelling can act as a valuable tool for communication and intereaction at the local level (Faulkner et al., 2007).

At larger scale, there is a demand from national, supernational and international organizations as well as the re-insurance industry to have continental and global flood hazard maps (Pappenberger et al., 2012, Alfieri et al., 2013a; Winsemius et al., 2013). Hyperresolution continental scale maps are emerging as computationally feasible, for example, Alfieri et al (2013a) produced European maps using 100m topographic data. The results are clearly not ideal for smaller catchments and those with significant unrepresented defences and underline the difference between such a continental scale application and the more local mapping initiatives which are mainly driven by available local information, such as the England and Wales maps described above. This case nicely demonstrates that it is the topographic data and lack of local information on defence structures that limit the results, and not really the model itself. Any new parameterisation or process representation would have little effect until these basic data needs are met. It is thus important to evaluate the most important sources of epistemic uncertainty in trying to improve local predictions in hyperresolution models. 
Feedback about model adequacy from local stakeholders is one way of reducing ignorance and will be an important driver for hyperresolution modelling.

\section{Conclusions}

It is clear that earth system models will gradually move to higher and hyperresolution grid scales. The demand to do so is driven by the need to resolve finer scales of motion in the atmosphere and oceans. It is also clear, however, that particularly in the subsurface terrestrial components of such models, hyperresolution ignorance of the appropriate of process parameterisations and effective parameter values will remain a significant constraint for the foreseeable future. The question then arises as to how best to counter such ignorance and uncertainties in applying such models when most sources of information at hyperresolution are indirect and may be incommensurate with model predicted variables. These issues mean that there will be significant uncertainty associated with hyperresolution predictions. Any evaluation of such uncertainty, as in any ensemble forecasting system, then demands computational resource that is in direct competition with the implementation of finer resolution solutions.

There is one real advantage of hyperresolution model outputs in this respect, however. As local model outputs start to be presented in visual form to local stakeholders then they will be subjected to much more demanding local evaluations. An evaluation of model uncertainty is then of some advantage to the modeller since an uncertain model output is much less likely to be obviously wrong than a simple deterministic prediction. Feedback from local stakeholders will, however, help to identify the obvious deficiencies in model predictions even if it will be difficult to pose such an evaluation within a formal hypothesis testing framework because of the dominance of epistemic over aleatory uncertainties.

\section{References}

Albergel, C., J.-C. Calvet, A.-L. Gibelin, S. Lafont, J.-L. Roujean, C. Berne, O. Traulle, and N. Fritz, 2010, Observed and modelled ecosystem respiration and gross primary production of a grassland in southwestern France. Biogeosciences, 7, 1657-1668.

Alfieri, L., Salamon, P., Bianchi, A., Neal, J., Bates, P. and Feyen, L. 2013a, Advances in pan-European flood hazard mapping. Hydrol. Process.. doi: 10.1002/hyp.9947

Alfieri, L., Burek, P., Dutra, E., Krzeminski, B., Muraro, D., Thielen, J., and Pappenberger, F., 2013b, GloFAS global ensemble streamflow forecasting and flood early warning, Hydrol. Earth Syst. Sci., 17, 1161-1175, doi:10.5194/hess-17-1161-2013.

Antonarakis, A. S., Richards, K. S., \& Brasington, J. 2008. Object-based land cover classification using airborne LiDAR. Remote Sensing of Environment, 112(6), 2988-2998.

Baldauf, Michael, Axel Seifert, Jochen Förstner, Detlev Majewski, Matthias Raschendorfer, Thorsten Reinhardt, 2011. Operational Convective-Scale Numerical Weather Prediction with the COSMO Model: Description and Sensitivities. Mon. Wea. Rev., 139, 3887-3905. doi: http://dx.doi.org/10.1175/MWR-D$\underline{10-05013.1}$ 
Balsamo, G., P. Viterbo, A. Beljaars, B. van den Hurk, M. Hirschi, A.K. Betts, and K. Scipal, 2009. A Revised Hydrology for the ECMWF Model: Verification from Field Site to Terrestrial Water Storage and Impact in the Integrated Forecast System. J. Hydrometeor., 10, 623-643.

Barling, R. D., Moore, I. D., and Grayson, R. B. 1994. A quasi-dynamic wetness index for characterising the spatial distribution of zones of surface saturation and soil water content, Wat. Resour. Res., 30, 10291044.

Bashford, K. E., Beven, K. J. and Young, P C, 2002, Observational data and scale dependent parameterisations: explorations using a virtual hydrological reality, Hydrol. Process.,16(2), 293-312.

Beven, K. J, 1981, Comments on 'A stochastic-conceptual analysis of rainfall-runoff processes on a hillslope' by R. Allan Freeze. Water Resources Research, 17(2), 431-432.

Beven, K. J. 1989, Changing ideas in hydrology: the case of physically based models. J. Hydrology, 105, 157-172.

Beven, K J, 2006, The Holy Grail of Scientific Hydrology: Systems Science, 10, 609-618.

Beven, K J, 2010, Preferential flows and travel time distributions: defining adequate hypothesis tests for hydrological process models, Hydrol. Process. 24: 1537-1547

Beven, K J, 2012, Causal models as multiple working hypotheses about environmental processes, Comptes Rendus Geoscience, Académie de Sciences, Paris, 344: 77-88, doi:10.1016/j.crte.2012.01.005 .

Beven, K. J. and Alcock, R., 2012, Modelling everything everywhere: a new approach to decision making for water management under uncertainty, Freshwater Biology, 56, doi:10.1111/j.13652427.2011.02592.x

Beven, K J, Buytaert, W and Smith, L. A., 2012a, On virtual observatories and modeled realities (or why discharge must be treated as a virtual variable), Hydrological Processes, DOI: 10.1002/hyp.9261

Beven, K J, and H. L. Cloke, 2012, Comment on Wood et al (2011) Hyperresolution global land surface modeling: Meeting a grand challenge for monitoring Earth's terrestrial water, Water Resources Research, 48, W01801, DOI:10.1029/2011WR010982

Beven, K.J., Germann, P. 1982, 'Macropores and water flow in soils", Water Resources Research, 18(5), 1311-1325.

Beven, K. J. and Germann, P. F., 2013, Macropores and water flow in soils revisited, Water Resour. Res., 49(6): 3071-3092 DOI: 10.1002/wrcr.20156

Beven, K J, Lamb, R, Leedal, D T, and Hunter, N, 2013, Communicating uncertainty in flood risk mapping: a case study, J. River Basin Manaaement., in press.

Beven, K. J., Leedal, D. T., McCarthy, S., 2014, Framework for assessing uncertainty in fluvial flood risk mapping, as CIRIA report C721, 2014, at

http://www.ciria.org/Resources/Free_publications/fluvial flood risk mapping.aspx, CIRIA: London

Beven, K. J., Smith, P. J., and Wood, A., 2011, On the colour and spin of epistemic error (and what we might do about it), Hydrol. Earth Syst. Sci., 15, 3123-3133, doi: 10.5194/hess-15-3123-2011.

Beven, K., P. Smith, I. Westerberg, and J. Freer, 2012b, Comment on "Pursuing the method of multiple working hypotheses for hydrological modeling" by P. Clark et al., Water Resour. Res., 48, W11801, doi:10.1029/2012WR012282. 
Beven, K. J., and Smith, P. J., 2014, Concepts of Information Content and Likelihood in Parameter Calibration for Hydrological Simulation Models, ASCE J. Hydrol. Eng. DOI: 10.1061/(ASCE)HE.19435584.0000991.

Beven, K J and Westerberg, I, 2011, On red herrings and real herrings: disinformation and information in hydrological inference, Hydrological Processes, 25, 1676-1680, DOI: 10.1002/hyp.7963.

Binley, A.M., Elgy, J., Beven, K.J. 1989a, A physically-based model of heterogeneous hillslopes. I. Runoff production. Water Resources Research, 25(6), 1219-1226.

Binley, A.M., Beven, K.J., Elgy, J. 1989b, A physically-based model of heterogeneous hillslopes. II. Effective hydraulic conductivities. Water Resources Research, 25(6), 1227-1233

Binley, A and Beven, K J, 2003, Vadose zone model uncertainty as conditioned on geophysical data, Ground Water, 41(2), 119-127.

Blyth, E., Gash, J., Lloyd, A., Pryor, M., Weedon, G. P., \& Shuttleworth, J. 2010. Evaluating the JULES land surface model energy fluxes using FLUXNET data. Journal of Hydrometeorology, 11(2), 509-519.

Boussetta, S., G. Balsamo, A. Beljaars, A. Agusti-Panareda, J.-C. Calvet, C. Jacobs, B. van den Hurk, P. Viterbo, S. Lafont, E. Dutra, L. Jarlan, M. Balzarolo, D. Papale, G. van der Werf, 2013, Natural land carbon dioxide exchanges in the ECMWF Integrated Forecasting System: Implementation and offline validation, J. Geophys. Res., 118(12), 5923-5946, DOI: 10.1002/jgrd.50488

Casas, A., Lane, S. N., Yu, D., \& Benito, G. 2010. A method for parameterising roughness and topographic sub-grid scale effects in hydraulic modelling from LiDAR data. Hydrology and Earth System Sciences Discussions, 7(2), 2261-2299.

Chrisman, B. and M. Zreda, 2013: Quantifying mesoscale soil moisture with the cosmic-ray rover, Hydrology and Earth System Science 17, 5097-5108, doi:10.5194/hess-17-5097-2013.

Cloke, H. L., \& Pappenberger, F. (2009). Ensemble flood forecasting: a review. J. Hydrology, 375(3), 613626.

Cloke, H. L., Jeffers, C., Wetterhall, F., Byrne, T., Lowe, J., \& Pappenberger, F. 2010. Climate impacts on river flow: projections for the Medway catchment, UK, with UKCP09 and CATCHMOD. Hydrological Processes, 24(24), 3476-3489.

Cloke, H. L., Wetterhall, F., He, Y., Freer, J. E., \& Pappenberger, F. 2012. Modelling climate impact on floods with ensemble climate projections. Quarterly Journal of the Royal Meteorological Society.

Crossley, A., Lamb, R., Waller, S. and Dunning P., 2010. Fast 2D Flood Modelling using GPU Technology. European Geosciences Union, General Assembly, Vienna, Austria, May 2010.

Dee, D. P., Uppala, S. M., Simmons, A. J., Berrisford, P., Poli, P., Kobayashi, S., Andrae, U., Balmaseda, M. A., Balsamo, G., Bauer, P., Bechtold, P., Beljaars, A. C. M., van de Berg, L., Bidlot, J., Bormann, N., Delsol, C., Dragani, R., Fuentes, M., Geer, A. J., Haimberger, L., Healy, S. B., Hersbach, H., Hólm, E. V., Isaksen, L., Kållberg, P., Köhler, M., Matricardi, M., McNally, A. P., Monge-Sanz, B. M., Morcrette, J.-J., Park, B.-K., Peubey, C., de Rosnay, P., Tavolato, C., Thépaut, J.-N. and Vitart, F., 2011, The ERA-Interim reanalysis: configuration and performance of the data assimilation system. Q.J.R. Meteorol. Soc., 137: 553-597. doi: 10.1002/qj.828

Dorigo, W. A., Wagner, W., Hohensinn, R., Hahn, S., Paulik, C., Xaver, A., Gruber, A., Drsuch, M., Mecklenberg, S., Robock, A.,van Oevelen, P. \& Jackson, T., 2011. The International Soil Moisture Network: a data hosting facility for global in situ soil moisture measurements. Hydrology and Earth System Sciences, 15(5), 1675-1698. 
Drusch, Matthias, Pedro Viterbo, 2007, Assimilation of Screen-Level Variables in ECMWF's Integrated Forecast System: A Study on the Impact on the Forecast Quality and Analyzed Soil Moisture. Mon. Wea. Rev., 135, 300-314.

Ebel B. A., Loague K., Montgomery D. R. and Dietrich W. E., 2008, Physics-based continuous simulation of long-term near-surface hydrologic response for the Coos Bay experimental catchment. Water Resources Research, 44:W07417. DOI: 10.1029/2007WR006442,

Emanuel, R. E., Hazen, A. G., McGlynn, B. L., \& Jencso, K. G. 2013. Vegetation and topographic influences on the connectivity of shallow groundwater between hillslopes and streams. Ecohydrology.

Entekhabi, D., Njoku, E. G., O'Neill, P. E., Kellogg, K. H., Crow, W. T., Edelstein, W. N., et al.. 2010. The soil moisture active passive (SMAP) mission. Proceedings of the IEEE, 98(5), 704-716.

Environment Agency 2013, Updated Flood Map for Surface Water - National Scale Surface Water Flood Mapping Methodology, Environment Agency Horizon House, Bristol, UK, 54pp.

Faulkner, D.S., 1999. Flood Estimation Handbook. Volume 2: Rainfall Frequency Estimation. Institute of Hydrology, 110 pages.

Faulkner, H, Parker, D, Green, C, Beven, K, 2007, Developing a translational discourse to communicate uncertainty in flood risk between science and the practitioner, Ambio, 16(7), 692-703

Feyen, L., \& Caers, J. 2006. Quantifying geological uncertainty for flow and transport modeling in multimodal heterogeneous formations. Advances in Water Resources, 29(6), 912-929.

Franks, S and Beven, K J, 1997, Estimation of evapotranspiration at the landscape scale: a fuzzy disaggregation approach, Water Resources Research, 33(12), 2929-2938.

Freer, J., J. McDonnell, K. J. Beven, N. E. Peters, D. Burns, R. P. Hooper, B. Aulenbach, and C. Kendal, 2002, The role of bedrock topography on subsurface stormflow. Water Resources Research, 38(12), W01269, $10.1029 / 2001$ WR000872

Freeze, R. A. 1975. A stochastic-conceptual analysis of one-dimensional groundwater flow in nonuniform homogeneous media. Water Resources Research, 11(5), 725-741.

Freeze, R. A. 1980. A stochastic-conceptual analysis of rainfall-runoff processes on a hillslope. Water Resources Research, 16(2), 391-408.

Golding, B. W. 2009. Long lead time flood warnings: reality or fantasy?. Meteorological Applications, 16(1), 3-12.

Gudmundsson, L., Tallaksen, L. M., Stahl, K., Clark, D. B., Dumont, E., Hagemann, S.,et al. 2012. Comparing large-scale hydrological model simulations to observed runoff percentiles in Europe. Journal of Hydrometeorology, 13(2), 604-620.

Guilleminot, J., Soize, C., \& Ghanem, R. G. (2012). Stochastic representation for anisotropic permeability tensor random fields. International Journal for Numerical and Analytical Methods in Geomechanics, 36(13), 1592-1608.

Haddeland, I. and 23 co-authors, 2011: Multimodel Estimate of the Global Terrestrial Water Balance: Setup and First Results. J. Hydrometeor, 12, 869-884, doi: http://dx.doi.org/10.1175/2011JHM1324.1

Hannah, D. M., Demuth, S., van Lanen, H. A. J., Looser, U., Prudhomme, C., Rees, G., Stahl, K. and Tallaksen, L. M. 2011, Large-scale river flow archives: importance, current status and future needs. Hydrol. Process., 25: 1191-1200. doi: 10.1002/hyp.7794. 
Henriksen H. J., Troldborg L., Hojberg A. L. and Refsgaard J. C. 2008, Assessment of exploitable groundwater resources of Denmark by use of ensemble resource indicators and a numerical groundwater-surface water model. Journal of Hydrology, 348:224-240, 2008.

Heppner C. S., Loague K. and VanderKwaak J. E. 2007, Long-term InHM simulations of hydrologic response and sediment transport for the R-5 catchment. Earth Surface Processes and Landforms, $32: 1273-1292 .$.

Hunter, N, Waller, S, Balmbra, V, Hankin, B, Faulkner, D, Lamb, R, Horritt, M, Wyse, P., 2010, Broad Scale Mapping of Surface Water Flooding - Present Status and Future Improvements, Proceedings of the Environment Agency FCRM10 Conference, 29 June - 1 July 2010, Telford Conference Centre, Paper 080.

Ines, A. V., \& Hansen, J. W., 2006. Bias correction of daily GCM rainfall for crop simulation studies. Agricultural and forest meteorology, 138(1), 44-53.

Kauffeldt, A., S. Halldin, A. Rodhe, C.-Y. Xu, and I. K. Westerberg, 2013, Disinformative data in large-scale hydrological modelling, Hydrol. Earth Syst. Sci., 17, 2845-2857, 2013

Kollet, S. J., Maxwell, R. M., Woodward, C. S., Smith, S., Vanderborght, J., Vereecken, H., \& Simmer, C., 2010. Proof of concept of regional scale hydrologic simulations at hydrologic resolution utilizing massively parallel computer resources. Water resources research, 46(4).

Lamb, R., Crossley, A. and Waller, S., 2009. A Fast Two-Dimensional Floodplain Inundation Model. Proceedings of the ICE - Water Management 162(6), 363-370.

Lane S. J. 1998, Hydraulic modelling in hydrology and geomorphology: A review of high resolution approaches. Hydrological Processes, 12:1131-1150.

Lane S., Odoni N., Landstr "om C., Whatmore S. J.,Ward N. and Bradley S. 2011, Doing flood risk science differently: An experiment in radical scientific method. Transactions of the Institute of British Geographers, 36:15-36.

Lawrence, D.M., K.W. Oleson, M.G. Flanner, P.E. Thornton, S.C. Swenson, P.J. Lawrence, X. Zeng, Z.-L. Yang, S. Levis, K. Sakaguchi, G.B. Bonan, and A.G. Slater, 2011: Parameterization improvements and functional and structural advances in version 4 of the Community Land Model. J. Adv. Model. Earth Sys., 3, DOI: 10.1029/2011MS000045.

Leedal, D T, J. Neal, K. Beven, P. Young and P. Bates, 2010, Visualization approaches for communicating real-time flood forecasting level and inundation information, J. Flood Risk Management, 3: 140-150

Lelièvre, P. G., \& Farquharson, C. G. 2013. Gradient and smoothness regularization operators for geophysical inversion on unstructured meshes. Geophysical Journal International, 195(1), 330-341.

Loague K. 1990, R-5 revisited: 2. Reevaluation of a quasi-physically based rainfall-runoff model with supplemental information. Water Resources Research, 26:973-987.

Loague K., Gander G. E., VanderKwaak J. E., Abrams R. H. and Kyriakidis P. C. 2000, Simulating hydrologic response for the R-5 catchment: A never ending story. Journal of Floodplain Management, 1:57-83.

McDonnell, J J and Beven, K J, 2014, Debates-The future of hydrological sciences: A (common) path forward? A call to action aimed at understanding velocities, celerities, and residence time distributions of the headwater hydrograph, Water Resour. Res., 50, doi:10.1002/2013WR015141.

McMillan, H., Freer, J., Pappenberger, F., Krueger, T., \& Clark, M. 2010. Impacts of uncertain river flow data on rainfall-runoff model calibration and discharge predictions. Hydrological Processes, 24(10), 12701284.

McMillan, H., Krueger, T., \& Freer, J. 2012. Benchmarking observational uncertainties for hydrology: rainfall, river discharge and water quality. Hydrological Processes, 26(26), 4078-4111. 
Meerschaert, M. M., Dogan, M., Dam, R. L., Hyndman, D. W., \& Benson, D. A. 2013. Hydraulic conductivity fields: Gaussian or not?. Water Resources Research, 49(8), 4730-4737.

Michael, H. A., Li, H., Boucher, A., Sun, T., Caers, J., \& Gorelick, S. M. 2010. Combining geologic-process models and geostatistics for conditional simulation of 3-D subsurface heterogeneity. Water Resources Research, 46(5), W05527

Mitchell, S, Freer, J and Beven, KJ, 2009, Multiple sources of predictive uncertainty in modeled estimates of net ecosystem CO2 exchange, Ecol. Model. 220: 3259-3270, doi:10.1016/j.ecolmodel.2009.08.021

Mitchell, S, Beven, K J, Freer, J and Law, B., 2011, Processes influencing model-data mismatch in droughtstressed, fire-disturbed, eddy flux sites. JGR-Biosciences, 116: doi:10.1029/2009JG001146

Mohanty, B. P. 2013. Soil hydraulic property estimation using remote sensing: A review. Vadose Zone Journal, 12(4).

Musgrave, H., \& Binley, A. 2011. Revealing the temporal dynamics of subsurface temperature in a wetland using time-lapse geophysics. Journal of Hydrology, 396(3), 258-266.

Neal. J., C Keef, P Bates, K J Beven and D T Leedal, 2013, Probabilistic flood risk mapping including spatial dependence, Hydrological Processes, 27: 1349-1363, doi: 10.1002/hyp.9572

Odoni, N. A., \& Lane, S. N. 2010. Knowledge-theoretic models in hydrology. Progress in Physical Geography, 34(2), 151-171.

Pacific, V. J., McGlynn, B. L., Riveros-Iregui, D. A., Welsch, D. L., \& Epstein, H. E. 2011. Landscape structure, groundwater dynamics, and soil water content influence soil respiration across riparian-hillslope transitions in the Tenderfoot Creek Experimental Forest, Montana. Hydrological Processes, 25(5), 811827.

Pappenberger, F., Beven, K.J., Frodsham, K., Romanovicz, R. and Matgen, P., 2007. Grasping the unavoidable subjectivity in calibration of flood inundation models: a vulnerability weighted approach. Journal of Hydrology, 333, 275-287.

Pappenberger, F., Dutra, E., Wetterhall, F., and Cloke, H. L., 2012, Deriving global flood hazard maps of fluvial floods through a physical model cascade, Hydrol. Earth Syst. Sci., 16, 4143-4156, doi:10.5194/hess16-4143-2012, 2012.

Pappenberger, F., Thielen, J., del Medico, M., 2010, The impact of weather forecast improvements on large scale hydrology: analysing a decade of forecasts of the European Flood Alert System, Hydrological Processes, 25(7), DOI : 10.1002/hyp.7772, 2010

Pappenberger, F., E. Stephens, J. Thielen, P. Salamon, D. Demeritt, S. J. Andel,, F. Wetterhall, and L. Alfieri, 2013, Visualizing probabilistic flood forecast information: Expert preferences and perceptions of best practice in uncertainty communication. Hydrol. Processes, 27, 132-146, doi:10.1002/hyp.9253.

Perri, M. T., Cassiani, G., Gervasio, I., Deiana, R., \& Binley, A., 2012. A saline tracer test monitored via both surface and cross-borehole electrical resistivity tomography: Comparison of time-lapse results. Journal of Applied Geophysics, 79, 6-16.

Piani, C., Weedon, G. P., Best, M., Gomes, S. M., Viterbo, P., Hagemann, S., \& Haerter, J. O., 2010. Statistical bias correction of global simulated daily precipitation and temperature for the application of hydrological models. Journal of Hydrology, 395(3), 199-215.

Richardson DS, Bidlot J, Ferranti L, Haiden T, Hewson T, Janousek M, Prates F \& Vitart F., 2013, Evaluation of ECMWF forecasts, including 2012-2013 upgrades. ECMWF Technical Memorandum 710 November 2013. ECMWF. 55pp. doi: http://dx.doi.org/10.1175/MWR3309.1 
Smith, L., \& Schwartz, F. W. 1980. Mass transport: 1. A stochastic analysis of macroscopic dispersion. Water Resources Research, 16(2), 303-313.

Smith, P. J., K.J. Beven, D. Leedal, A.H. Weerts, and P. C. Young, 2014, Testing probabilistic adaptive realtime flood forecasting models, J. Flood Risk Management, in press.

Smith, R. E., \& Hebbert, R. H. B., 1979. A Monte Carlo analysis of the hydrologic effects of spatial variability of infiltration. Water Resources Research, 15(2), 419-429.

Smith, T., Marshall, L., McGlynn, B., \& Jencso, K., 2013. Using field data to inform and evaluate a new model of catchment hydrologic connectivity. Water Resources Research, 49(10), 6834-6846.

Tian, X., Xie, Z., Dai, A., Shi, C., Jia, B., Chen, F., \& Yang, K., 2009. A dual-pass variational data assimilation framework for estimating soil moisture profiles from AMSR-E microwave brightness temperature. Journal of Geophysical Research, 114(D16), D16102.

Wang, H., Jia., L., Steffen, H., Wu, P., Jian, L., Hsu, H., Xiang, L., Wang, Z., Hu, B., 2013, Increased water storage in North America and Scandinavia from GRACE gravity data Nature Geosci, Vol. 6, No. 1. (January 2013), pp. 38-42, doi:10.1038/ngeo1652

Weusthoff, Tanja, Felix Ament, Marco Arpagaus, Mathias W. Rotach, 2010, Assessing the Benefits of Convection-Permitting Models by Neighborhood Verification: Examples from MAP D-PHASE. Mon. Wea. Rev., 138, 3418-3433. doi: http://dx.doi.org/10.1175/2010MWR3380.1

Wetterhall, F., Pappenberger, F., Alfieri, L., Cloke, H. L., Thielen-del Pozo, J., Balabanova, S., Daňhelka, J., Vogelbacher, A., Salamon, P., Carrasco, I., Cabrera-Tordera, A. J., Corzo-Toscano, M., Garcia-Padilla, M., Garcia-Sanchez, R. J., Ardilouze, C., Jurela, S., Terek, B., Csik, A., Casey, J., Stankūnavičius, G., Ceres, V., Sprokkereef, E., Stam, J., Anghel, E., Vladikovic, D., Alionte Eklund, C., Hjerdt, N., Djerv, H., Holmberg, F., Nilsson, J., Nyström, K., Sušnik, M., Hazlinger, M., and Holubecka, M., 2013, HESS Opinions "Forecaster priorities for improving probabilistic flood forecasts", Hydrol. Earth Syst. Sci., 17, 4389-4399, doi:10.5194/hess-17-4389-2013.

Whatmore, S. J., Lane, S. N., Odoni, N. A., Ward, N., \& Bradley, S., 2011. Coproducing flood risk knowledge: redistributing expertise in criticalparticipatory modelling'. Environment and Planning A, 43, 1617-1633.

Wilby, R. L., 2010. Evaluating climate model outputs for hydrological applications. Hydrological Sciences $\begin{array}{lllll}\text { Journal-Journal des Sciences } \quad H y d r o l o g i q u e s, & \text { 55(7), }\end{array}$

Wilson, K., Goldstein, A., Falge, E., Aubinet, M., Baldocchi, D., Berbigier, P., Bernhofer, C., Ceulemans, R., Dolman, H., Field, C. Grelle, A., Ibrom, A., Law, B.E., Kowalski, A., Meyers, T., Moncrieff, J., Monson, R., Oechel, W., Tenhunen, J., Valentini, R., and Verma, S., 2002, Energy balance closure at FLUXNET sites, Agricultural and Forest Meteorology, 113 (1-4): 223-243, http://dx.doi.org/10.1016/S01681923(02)00109-0.

Winsemius, H. C., Van Beek, L. P. H., Jongman, B., Ward, P. J., and Bouwman, A., 2013, A framework for global river flood risk assessments, Hydrol. Earth Syst. Sci., 17, 1871-1892, doi:10.5194/hess-17-18712013.

Wood, E.F., Roundy, J.K., Troy T.J, van Beek L.P.H., Bierkens M.F.P., Blyth E., de Roo A., Döll P., Ek M., Famiglietti J., Gochis D., van de Giesen N. Houser P., Jaffé P.R., Kollet S. Lehner B., Lettenmaier DP, PetersLidard C., Sivapalan M., Sheffield J., Wade A., Whitehead P., 2011, Hyperresolution global land surface modeling: Meeting a grand challenge for monitoring Earth's terrestrial water Water Resources Research, Vol. 47, W05301, doi:10.1029/2010WR010090,

Zinn, B., and C. F. Harvey, 2003, When good statistical models of aquifer heterogeneity go bad: A comparison of flow, dispersion, and mass transfer in connected and multivariate Gaussian hydraulic conductivity fields, Water Resour. Res., 42(3), 1051, doi:10.1029/2001WR001146. 
Zreda, M., W.J. Shuttleworth, X. Zeng, C. Zweck, D. Desilets, T. Franz and R. Rosolem, 2012. COSMOS: The COsmic-ray Soil Moisture Observing System. Hydrology and Earth System Science 16, 4079-4099, doi:10.5194/hess-16-1-2012. 